BIRD COLORATION 



\section{Bird Coloration}

VOLUME I

Mechanisms and Measurements

EDITED BY

Geoffrey E. Hill

and Kevin J. McGraw

HARVARD UNIVERSITY PRESS

Cambridge, Massachusetts

London, England · 2006 
Copyright () 2006 by the President and Fellows of Harvard College All rights reserved

Printed in the United States of America

\section{Library of Congress Cataloging-in-Publication Data}

Bird coloration / edited by Geoffrey E. Hill and Kevin J. McGraw.

p. $\mathrm{cm}$.

Includes bibliographical references (p. ) and indexes.

ISBN 0-674-01893-1 (alk. paper) (volume 1)

ISBN 0-674-02176-2 (alk. paper) (volume 2)

1. Birds-Color. I. Hill, Geoffrey E. (Geoffrey Edward) II. McGraw, Kevin J.

QL673.B555 2006

$598.147^{\prime} 2-\mathrm{dc} 22$ 